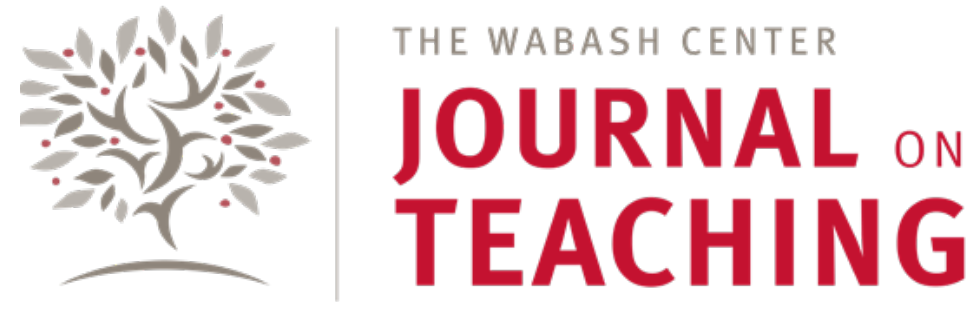

SPECIAL TOPIC

\title{
Transformative Concepts and Troublesome Knowledge: Toward a Threshold Concept Framework for Biblical Studies
}

\author{
John Van Maaren \\ McMaster University
}

\begin{abstract}
Threshold concepts (TCs) are conceptual gateways that students must pass through in order for learning to progress, but which are often navigated with considerable difficulty. They are therefore both transformative and troublesome for student learning. While individual TCs have been identified in related disciplines, no study has addressed TCs for ways of thinking and practicing in biblical studies. After introducing the TC framework, this essay takes a first step toward developing a TC framework for biblical studies by proposing a set of TCs for the discipline. In conclusion, this essay provides guidelines, with practical examples, for integrating TCs into the biblical studies classroom. Also published in this issue of the journal, see three short essays by Richard S. Ascough, Tat-siong Benny Liew, and Jocelyn McWhirter, each describing a particular teaching strategy they use to address a key threshold concept in their biblical studies courses.
\end{abstract}

\section{KEYWORDS}

threshold concepts, biblical studies, threshold characteristics, troublesome knowledge, student learning

\section{Introduction}

Many experienced teachers can identify particular disciplinary concepts that, year after year, present the most formidable barriers to student understanding and disciplinary progress. ${ }^{1}$ One reason that these concepts may be consistently troublesome is that most students cannot easily accommodate them within their existing frame of meaning. Rather, students must reformulate their meaning frame in order to integrate the new concept. While such concepts - designated threshold concepts (henceforth TCs) - may be troublesome, they are also transformative for student meaning-making insofar as the new perspective occasions a new understanding of the subject - a transformation essential for student progress.

The potential contribution of TCs to enhance student learning has prompted organizations such as the Higher Education Academy (Mossley 2017) and the American Library Association (Association for College and Research Libraries 2015, 2) to promote TCs as a key pedagogical tool. While studies have identified TCs in as many as 259 disciplines (Land, Meyer,

1 Previous versions of this paper were presented in the Teaching Biblical Studies in an Undergraduate, Liberal Arts Context program unit of the annual meeting of the Society of Biblical Studies in Denver, Colorado (Van Maaren 2018b) and the Pedagogy of Bible Education conference hosted by the Mofet Institute, Tel Aviv (Van Maaren 2018a). I thank the participants for the constructive feedback which significantly improved this paper. The idea for this paper developed while working on two teaching and learning research projects with the Paul R. MacPherson Institute for Leadership, Innovation, and Excellence in Teaching at McMaster University. I especially thank Janette Barrington and Arshad Ahmad for their encouragement and constructive feedback. 
and Flanagan 2016, xii), and their value for theology and religion has been noted (Killen 2011), no study has identified TCs in biblical studies. ${ }^{2}$

In this paper, I identify five concepts that may function as TCs for the discipline of biblical studies. I first introduce the TC framework by summarizing the common characteristics of TCs and discuss their potential to enhance student learning. I then outline a preliminary list of TCs for biblical studies by appealing to related disciplines, especially history and literature, where significant work identifying TCs has already been done. ${ }^{3}$ This list is meant as a first step toward developing a TC framework for biblical studies. ${ }^{4}$ Lastly, I illustrate the contribution of TCs to student learning by providing practical examples for how these five TCs may be integrated into course design, assignment choices, presentation strategies, classroom activities, and assessment.

\section{Threshold Concept Characteristics and Their Contributions to Student Learning}

Since TCs were first introduced (Meyer and Land 2002; 2003), a vast scholarly output has developed around their conceptualization, identification, and implementation in classroom settings. ${ }^{5}$ TCs have "emerged as a set of transferable or portable ideas across disciplinary contexts, which offer new insights into teaching and learning, and as a theoretical framework that is both explanatory and "actionable"' (Land, Meyer, and Smith 2008, xi). After extensive scrutiny, the basic concept has remained stable: A TC is "akin to a portal, opening up a new and previously inaccessible way of thinking about something. It represents a transformed way of understanding, or interpreting, or viewing something without which the learning cannot progress" (Meyer and Land 2003, 412). Here I summarize TC characteristics and identify their contribution to student learning.

\section{Threshold characteristics}

TCs tend to have four characteristics. ${ }^{6}$ First, a TC is transformative in that, once understood, it "occasions a significant shift in the perception of the subject." This is the non-negotiable characteristic of TCs (Baillie, Bowden, and Meyer 2013 , 229; Meyer et al. 2016, xii) and, in terms of the conceptual change literature, constitutes "profound" rather than "basic" conceptual change (Davies and Mangan 2007, 713-715). Basic conceptual change involves reworking or building upon prior concepts such as when a single concept is differentiated into multiple concepts, or two existing concepts are seen to be the same. In contrast, profound conceptual change involves a transformed perspective on the subject that may involve integrating overarching concepts so that the whole is greater than its parts, or the acquisition of organizing models that allow students to construct arguments according to disciplinary ways of thinking and practicing.

Whereas the acquisition of core concepts - conceptual building blocks that advance subject knowledge - involves basic conceptual change, learning TCs requires profound conceptual change (cf. Barradell 2013, 2). For example, on the one hand, the center of gravity - the point from which the weight of a body may be considered to act - builds upon and advances subject knowledge and so represents a core concept in the physical sciences that requires basic conceptual change. On the other hand, gravity - the idea that any two bodies attract one another with a force that is proportional to the product of their masses and inversely proportional to the distance between them - occasions a shift in perception of the natural world and exposes the interrelatedness of apparently disparate things. Therefore, gravity represents a TC in the natural sciences and, once understood, occasions profound conceptual change (Meyer and Land 2006, 6-7). While exclusive focus on transmitting core concepts to students represents a teacher-centered/information transfer approach

\footnotetext{
2 The closest is Rachelle Gilmour's study, which identifies the exodus event as a TC for the biblical writers, but does not address TCs for the discipline of biblical studies (2016). Individual TCs in the related disciplines of religion and online theological education have been identified (Morales and Barnes 2018; Mudge 2014).

3 This study aligns most closely with the type of scholarship of teaching and learning that Killen and Gallagher label “'Philosopher's Stone': Pedagogies and Theories" (2013).

4 See also three brief companion essays published in this issue of the journal. Each analyzes a particular threshold concept the authors have identified in their biblical studies classroom and describes a teaching strategy they have developed to address this challenge to students' learning: Richard S. Ascough, "Crossing the Threshold by Unlearning the 'Truth' in Biblical Studies”; Tat-siong Benny Liew, “Teaching the Bible as a Threshold Concept in a Liberal Arts Context”; and Jocelyn McWhirter, "All Interpretations Are Subjective."

5 Mick Flanagan's extensive bibliography (2019) lists 1726 TC publications by 1997 authors as of March 17, 2019.

6 These four characteristics, along with a fifth (bounded), are outlined by Meyer and Land (2003) who later added three more to the initial five: liminal, reconstitutive, and discursive (2005). For our purposes, we will focus only on the primary four characteristics.
} 
to teaching and may encourage passive learning, an emphasis on TCs in course syllabi and classroom pedagogy aligns with a student-centered/conceptual change approach to teaching (Saroyan and Trigwell 2015) - shown to encourage deep learning (Trigwell, Prosser, and Waterhouse 1999; Gibbs and Coffee 2004) - helping students to transform their conceptions of the phenomena they study (Trigwell and Prosser 2004, 413).

Second, a TC is often integrative in that "it exposes the previously hidden interrelatedness of something" (Meyer and Land 2003 , 4). By integrating concepts that previously appeared unrelated, the existing concepts may be redefined in terms of relations to other concepts rather than by a list of isolated characteristics. This accumulative effect may gradually impact all aspects of one's perception of the world. Third, acquisition of a TC is probably irreversible, insofar as the student may unlearn the changed perspective only with considerable effort. Whereas factual knowledge such as core concepts must be rehearsed in order to be retained, knowledge that restructures or integrates concepts like TCs impacts student understanding of the nature of knowledge. The effort required to unlearn TCs is confirmed by experts (those who have long-since crossed a conceptual threshold) who report difficulty understanding the trouble students have encountering a TC for the first time (Meyer and Land 2003, 415).

Finally, a TC is most often troublesome, as navigating the threshold may be done with difficulty and may cause an uncomfortable shift in identity. Meyer and Land identify six types of knowledge that may be troublesome (2003, 416-420; cf. Perkins 1999). (1) Ritual knowledge is existing knowledge that lacks meaning. It has a routineness to it, functioning as a ritualized response to, for example, a classroom question or examination prompt. Mathematic formulas often function this way. For example, calculus students may know how to find the derivative of an equation by memorizing formulae. However, without grasping how the derivative indicates the rate of change and describes a feature of the real world, the knowledge remains ritualized. (2) Inert knowledge is existing knowledge that is not activated. While the knowledge may be memorized, it is not integrated into students' perception of their lived experience. For example, students may learn and bemoan past societal injustices. However, without connecting knowledge of the past with their present reality to enable reflection on possible contemporary forms of injustice, the knowledge remains inert. (3) Foreign or alien knowledge is knowledge that comes from a perspective in conflict with one's own. For example, North American students of religion may have trouble understanding the sincerity of the Yazidi belief in an angel that appears in the form of a peacock and is venerated as an emanation of God - a belief that may seem radically foreign to many forms of western religiosity. Students may easily disregard alien knowledge by appeal to "common sense," short-cutting student learning. (4) Tacit knowledge is existing knowledge that is implicit and personal even as it may be shared by a community of practice. For example, expected gender roles within a community of practice may be learned by observation and imitation, and may remain tacit and unexamined. Meyer and Land note that tacit knowledge may override alien knowledge that students encounter in classroom settings (e.g., alternative gender roles) and that appears counter-intuitive. (5) In addition, some content knowledge may be experienced as conceptually difficult knowledge. This is especially prominent in STEM disciplines. In the humanities and social sciences, data analysis or the interdisciplinary use of theoretical models may be especially conceptually difficult. (6) Finally, discipline-specific discourses may constitute troublesome language as students encounter sometimes-familiar terms used in new ways. Examples include the term "culture" in social anthropology, and "religion" in religious studies. Troublesome language constitutes a specific type of conceptually difficult knowledge and is especially prominent in the humanities and social sciences as discourses develop to represent and privilege particular understandings.

In summary, the superordinate characteristic of a TC is its transformative potential. To the extent that a TC is also integrative, irreversible, and troublesome, it is more assuredly identified as a TC and may be integrated into course design and classroom pedagogy to increase student learning and disciplinary progress.

\section{The contribution of threshold concepts to student learning}

The importance of identifying TCs lies in the fact that they are essential for student progress, navigated with difficulty, and often presented only implicitly in course syllabi and classroom activities and presentations. Teachers, as experts in the discipline, likely acquired threshold capabilities long ago (crossed the disciplinary thresholds by learning the TCs) and may now perform the TC mental operations subconsciously. In the classroom this means that these disciplinary ways of thinking and practicing are often assumed, leaving students to discern, or perhaps guess, the essential mental operations required for thinking like a biblical scholar. Therefore, by identifying TCs, these implicit concepts may be made explicit and used to structure course design, assignment choices, presentation strategies, and classroom activities, (Timmermans and Meyer 2017, 5-6). 
Students enter the classroom with different relationships to a given TC. Some may have already acquired the threshold capability, some may not have, and some may be in the liminal space of navigating the threshold (Vidal, Smith, and Spetic 2015, 516-517). This variation in student learning may manifest itself in a bifurcation between "those who get it" and "those who do not." The difference may not be intelligence or effort, but relationship to a conceptual threshold which has been crossed only by "those who get it." Meyer, Land, and Davies (2008) outline four stages in the process of navigating a TC (each of which is experienced differently by individual students). (1) During the subliminal stage, before encountering the TC, the student possesses a tacit assumption about the content. (2) The pre-liminal stage begins when the student first encounters the TC and forms an initial impression. (3) During the liminal stage students enter and navigate the threshold. Leaving behind their previous understanding, they struggle to reconstitute their understanding by integrating the new concept. (4) Finally, in the post-liminal stage the student transcends the liminal space and arrives at a transformed understanding of the subject matter. Awareness of individual student relationships to the TCs enables teachers to pinpoint the particular needs of specific students and more equitably adopt a student-centered approach to teaching that is responsive to student needs.

\section{Toward a Threshold Concept Framework for Biblical Studies}

\section{Method}

To date, much of the work identifying TCs has been done in STEM disciplines such as medicine, mathematics, and engineering. This is partly because the more clearly-defined body of content knowledge in STEM disciplines makes a consensus set of TCs appear more feasible. However, within the social sciences and humanities, "ways of thinking and practicing" may also function as TCs (Meyer and Land 2006, 15). For example, opportunity cost is fundamental to thinking like an economist and is a TC in economics, a discipline fundamentally concerned with choice and scarcity (Reimann and Jackson 2006, 116; cf. Davies and Mangan 2007). One popular economic textbook identifies it as the first TC of economics and defines it as follows: "The opportunity cost of any activity is the sacrifice made to do it. It is the best thing that could have been done as an alternative" (Sloman and Wride 2009, 8). Crossing the threshold of opportunity cost represents a transformation from understanding changes as predetermined to seeing two sides of each choice. It expresses the basic interrelatedness of scarcity and choice, two fundamental concepts in economics (Shanahan and Meyer 2006).

A potential pitfall of identifying TCs is the power dynamics of creating normative sets of TCs which may have a totalizing or colonizing effect on disciplinary boundaries and content (Meyer and Land 2006, 16). This raises the question "Whose TCs?" and is especially relevant for the humanities and social sciences which have less agreed-upon content knowledge and therefore a wider spectrum of possible TCs.

In order to counteract bias, numerous scholars have advocated a "transactional curriculum inquiry" for identifying TCs (Barradell 2013; Cousin 2009, 201-212; Timmermans and Meyer 2017, 4-5). This approach draws upon various stakeholders in the educational process in order to ensure that the selected TCs are the most important for student learning. First, an initial list may be compiled for one's own discipline by consulting the existing literature on TCs in related disciplines. This cross-disciplinary approach allows the identification of TCs that may be shared across disciplinary boundaries as well as TCs which mark the boundary between disciplines, distinguishing, for example, biblical studies from history. Second, empirical data may be collected from teachers and students through interviews, focus groups, concept mapping, and so forth. On the one hand, teachers, as experts in the field, have acquired the disciplinary TCs and also have a first-hand perspective on which concepts students find troublesome and transformative year-after-year. On the other hand, students can report on their experiences encountering and navigating TCs (Barradell 2013, 269; Male 2012, 15). Finally, these three sources of data (TCs in other disciplines, teachers, and students) can be further refined through consultation with educational developers.

The list of TCS outlined below was developed by consulting the existing TC literature, especially in the related disciplines of history and literature. As a theoretical list, it represents the first step toward the development of a TC framework for biblical studies through a transactional curriculum inquiry. At the same time, the preliminary list is practical insofar as each individual TC may be used ad hoc in developing assignment choices, presentation strategies, and classroom activities that aim to make explicit the disciplinary ways of thinking and practicing in biblical studies.

In contrast to religious studies, whose content knowledge is notoriously difficult to define, the subject of biblical studies 
is a bit more straightforward. I take the content of biblical studies to be texts considered "biblical" by different religious traditions, whether the Tanakh, Old and New Testaments, Apocrypha, or additional texts included in other canonical lists and considered authoritative by their respective traditions. I take the study of these texts to include their interpretation, historical setting, origin, transmission, and reception history. While the term "biblical" most often refers to canonical texts of Jewish and Christian traditions, these TCs are transferable to any disciplinary boundaries focused on authoritative texts within religious traditions. As a set of TCs for biblical studies, I mean for this list to be useful in any course that includes any of the above aspects of the biblical texts as a primary focus whether in a biblical studies department, religious studies department, seminary curriculum, or elsewhere.

My approach to developing this preliminary list is by appeal to related disciplines, especially history and literature, where significantly more work on TCs has been done. I understand ways of thinking and practicing in biblical studies to overlap with history most directly in the use of the biblical texts as historical sources and in the re-creation of a historical context for textual interpretation. I understand biblical studies to overlap with literature especially in the ways of thinking and practicing related to creating meaning from the written text. I take biblical studies to differ from both history and literature most basically in the authoritative status accorded the biblical texts. While a distinction could be made between the discipline of biblical studies as taught at an institution with a commitment to the authoritative status of these texts (as seen, for example, in a statement of faith or core values) and institutions without limitations on academic freedom (cf. American Association of University Professors 1970), I focus only on the authoritative status as a feature of the biblical texts' reception.

\section{Threshold concepts in the discipline of history}

The identification of TCS in the study of history draws on empirical research about what it means to think historically (esp. Wineburg 1991, 2001). Thomas Andrews and Flannery Burke identify "five C's" of historical thinking: "Change over time, causality, context, complexity, and contingency" (2007, 32). Lendol Calder identifies six cognitive moves students must learn to think like expert historians: "Questioning, connecting, sourcing, making inferences, considering alternative perspectives, and recognizing limits to one's knowledge” (2006, 1364). Michael Coventry and colleagues discuss five inter-related themes: Approaching evidence contextually, confronting the constructed nature of any source, connecting evidence and scholarship; grasping the limits of different media (writing, and so forth) for representing history, and becoming "citizen historians" by connecting personally to history and making it public $(2006,1377)$. Arlene Díaz and colleagues identify "bottlenecks" for students learning to think historically. These include recognizing the variety of primary sources and interpreting them; recreating historical context and connecting it to a document, identifying and empathizing with people from another place and time, dealing with ambiguity and contradiction in historical sources, recognizing major points in primary and secondary sources, and producing some sense through connecting multiple sources (2008, 1222; cf. Lévesque 2008; Pace 2008).

Paul Sendziuk synthesizes the scholarship on ways of thinking historically and identifies two primary TCs for the study of history that I suggest also function as TCs for biblical studies: (1) "the past is a foreign country" and (2) the constructed and contested nature of historical understanding (2014; cf. Díaz et al. 2008). On the one hand, the radical otherness of the past ( $\mathrm{TC}_{1}$ ) requires historians to engage with the past on its own terms and includes ways of thinking that emphasize connecting imaginative recreation of historical context to document interpretation and empathy for historical characters from another time and place. On the other hand, the constructed and contested nature of historical understanding (TC 2) requires historians to contextualize and interrogate sources of historical evidence. This involves cognitive processes such as questioning, corroborating evidence, distinguishing and relating primary and secondary sources, and synthesizing multiple sources through mechanisms like causality, inference, and creativity. It also involves acknowledging the complexity of historical reconstruction through ambiguous and contradictory historical sources, the reciprocal relationship between artifact and interpreter, the limits of our knowledge and media of communication, and the contingency of history.

Sendziuk argues for a third TC, the contemporary relevance of studying history $(2014,178-179)$. While the value of historical study does not relate to ways of thinking historically, he argues that it represents a TC because the relevance of historical study is not immediately obvious for students, the vast majority of whom will not go on to a career as a historian. Sendziuk identifies the value of studying history to be the development of transferable critical thinking skills. I would add Coventry et al.'s emphasis on becoming “citizen historians” by having one's identity shaped by personally engaging historical persons and events, and making historical knowledge public (2006). 


\section{Threshold concepts in the discipline of literature}

Important work identifying threshold concepts in English literature has been carried out by Gina Wisker, Stuart Cameron, and Maria Antoniou at the University of Brighton, UK (2007). Their study used a transactional curriculum inquiry approach that included educational developers on the research team, consulted the existing TC literature from related disciplines, partnered with English literature lecturers to identify TCs in syllabi and conceptions of English literature, and conducted semi-structured interviews with students (Wisker, Cameron, and Antoniou 2007, 8-9, 11).

Their project identified four primary TCs for the discipline of English literature: context, interpretation, representation, and formal expression (Wisker 2015, 7). Wisker defines context as "the engagement of the literary work with [the] time, place, people's world views and values - and with the time, place, world views, and values of the reader." The first half of this definition - the original historical context - corresponds to the TC in the discipline of history that Sendziuk labels "the past is a foreign country." The second half - the reader's historical context - overlaps with Sendziuk's identification of the relevance of history as a TC insofar as the text/historical event is engaged through contemporary "world views and values." Further, though not included in Wisker's definition, the various historical contexts of past readers as part of the context finds a parallel in the study of reception history as part of biblical studies.

Wisker defines interpretation as when "readers, learners, [and] writers, interact with the text in context opening up new perspectives and ways of looking at the text and the world," $(2015,7)$. This second TC for English literature corresponds closely to the second TC in history - that is, the constructed and contested nature of historical understanding.

A third TC in English Literature - one that Wisker, Cameron, and Antoniou suggest is shared by all arts and humanities disciplines - is representation. For students to cross the representation threshold, they must grasp that the signifier in the text is more than the signified in the "real" world. The distinction between signifier and signified enables students to recognize that "elements in a text represent an argument, ideology, world view and that they function symbolically, metaphorically, in excess of their mimetic qualities” (Wisker et al. 2007, 9). Grasping representation is closely related to understanding what the writer's purpose is in composing a text.

A fourth TC for English literature is formal expression. This refers to the way that the formal, structural, linguistic, and generic choices enable aesthetic pleasure and communicate emotion, feelings, meaning, and perhaps a message (Wisker et al. 2007, 9). Formal expression in English literature overlaps with the emphasis in historical thinking that considers the limits of different media (writing, and so forth) for representing history.

The disciplines of history and literature provide a useful starting point for identifying TCs in biblical studies because of the overlap in ways of thinking and practicing with biblical studies, and because significant work identifying TCs has been done in each. Other related disciplines such as sociology, anthropology, geography, and classics have less developed TCS and so are less useful (Flanagan 2019). In the following section, I identify and illustrate five TCs for biblical studies and note additional TCs in disciplines outside history and literature that may be useful for certain biblical studies courses.

\section{A Preliminary Set of Threshold Concepts for Biblical Studies}

This study identifies five foundational TCs for the discipline of biblical studies. These are (1) the biblical world as a foreign country, (2) the constructed nature of biblical understanding, (3) the concept that everything is an argument, (4) the relevance of the academic study of the Bible, and (5) the effects of treating the biblical texts as authoritative. These are derived from TCs in history, literature, and what I take to be a distinguishing feature of biblical studies from history - the authoritative status of biblical texts among communities of practice. I will discuss each of these five in turn, explaining and showing how each may be transformative, integrative, and troublesome. I do not discuss irreversibility because, as I understand, this would require empirical data collection from students after having crossed the threshold. The essential characteristic of TCs is the transformative perspective shift on the part of the learner. The other characteristics are usually, but not always present. For example, not all economics students will experience opportunity cost as conceptually troublesome. However, to the extent that this preliminary TC set possesses each attribute, the justification for treating them as TCs becomes stronger. Table one below summarizes the threshold characteristics of each TC. 
TABLE 1: Threshold Concepts in Biblical Studies

\begin{tabular}{|l|l|l|l|}
\hline & Transformative & Integrative & Troublesome \\
\hline $\begin{array}{l}\text { Biblical world as } \\
\text { foreign country }\end{array}$ & $\begin{array}{l}\text { grasp that personal beliefs } \\
\text { cannot be assumed for biblical } \\
\text { writers and characters }\end{array}$ & $\begin{array}{l}\text { illuminates the effect of soci- } \\
\text { etal factors on contemporary } \\
\text { biblical understandings }\end{array}$ & $\begin{array}{l}\text { confronting alien knowledge } \\
\text { exposes tacit knowledge and } \\
\text { enables it to be examined }\end{array}$ \\
\hline $\begin{array}{l}\text { Constructed } \\
\text { nature of biblical } \\
\text { understanding }\end{array}$ & $\begin{array}{l}\text { adopt evidence-based ap- } \\
\text { proach that considers author- } \\
\text { ship, language, context, textual } \\
\text { integrity, etc. }\end{array}$ & $\begin{array}{l}\text { shows the reciprocal relation- } \\
\text { ship of historical reconstruction } \\
\text { and textual interpretation }\end{array}$ & $\begin{array}{l}\text { converting inert knowledge } \\
\text { into evidence-based contingent } \\
\text { knowledge }\end{array}$ \\
\hline $\begin{array}{l}\text { Everything is an } \\
\text { argument }\end{array}$ & $\begin{array}{l}\text { approach texts as artifacts } \\
\text { produced by real persons for } \\
\text { specific purposes }\end{array}$ & $\begin{array}{l}\text { connects textual features with } \\
\text { context by considering purpose } \\
\text { of textual composition }\end{array}$ & $\begin{array}{l}\text { confronting alien knowledge } \\
\text { exposes tacit knowledge and } \\
\text { enables it to be examined }\end{array}$ \\
\hline $\begin{array}{l}\text { Relevance of } \\
\text { biblical studies }\end{array}$ & $\begin{array}{l}\text { view academic approach to } \\
\text { the Bible as asset for personal } \\
\text { meaning-making }\end{array}$ & $\begin{array}{l}\text { links textual interpretation with } \\
\text { reception history }\end{array}$ & $\begin{array}{l}\text { exposing the relevance of ritual } \\
\text { knowledge creates identity } \\
\text { vulnerability }\end{array}$ \\
\hline $\begin{array}{l}\text { Effects of biblical } \\
\text { authority }\end{array}$ & $\begin{array}{l}\text { analyze authority as a contin- } \\
\text { gent historical factor }\end{array}$ & $\begin{array}{l}\text { embeds authority within the } \\
\text { exploration of historical contin- } \\
\text { gencies }\end{array}$ & $\begin{array}{l}\text { moving authority from tacit } \\
\text { knowledge to explanandum } \\
\text { can destabilize identity }\end{array}$ \\
\hline
\end{tabular}

\section{The biblical world as a foreign country}

A first concept that I suggest functions as a TC for the discipline of biblical studies is that the world of the Bible is a foreign country - that is, the radical otherness of the life experiences, practices, beliefs, motivations, and so forth of biblical characters and writers. This TC takes its name from the corresponding TC in history and is also shared with literature (context). An example of datum that may prompt students to navigate this threshold is the idea that many biblical writers assumed the existence of many deities (Heiser 2008). Take, for example, the decalogue injunction that "You shall have no other gods before me" (Exodus 20:3 NRSV) or the psalmist's tribute that "the Lord is a great god, and a great king above all gods" (Psalm 95:3).

The perception shift that crossing this threshold prompts - that is, the student's transformation - is an awareness that personal beliefs cannot be imputed to biblical writers and characters and consequently that the student must engage the past on its own terms. This involves "ways of thinking" that include imaginative recreation of the past, linking a reconstructed historical context to textual interpretation, and empathy for historical characters. An awareness of the radical otherness of persons in antiquity may also be integrative insofar as the gap between ancient and present-day worldviews illuminates the impact of other societal factors on students' encounter with the biblical text. So, for example, a student may ask what historical processes caused a decrease in henotheism (allegiance to one deity) as seen in some biblical writers, and an increase in monotheism or atheism, or they may inquire about the implicit assumptions that guide their reading of the text. In this way, an awareness of the radical otherness of the biblical world links reading biblical texts with western history, reception history, and interpretive approaches. Finally, the radical otherness of the biblical world can be experienced as troublesome for students as their encounter with alien knowledge exposes tacit knowledge that is then vulnerable to critical examination. As discussed above, alien knowledge comes from a perspective that is not one's own while tacit knowledge remains personal, implicit, and often unexamined. When students encounter the idea that the decalogue, or perhaps Paul, believed in the existence of other deities, their existing tacit knowledge (for example, that all biblical writers were monotheists) may override the alien knowledge, preventing the transformed perspective. For others, the encounter with the radical otherness of biblical characters may expose tacit but deeply engrained assumptions that may now appear vulnerable, causing an uncomfortable shift in identity.

\section{The constructed nature of biblical understanding}

A second TC that I suggest biblical studies shares with both history and literature is the constructed nature of the subject knowledge. That is, through interpretation, the sources are used to create new knowledge for today. I use "biblical understanding" as a catch-all for what students know about the Bible - especially its content, history, historical setting, origin, 
transmission, reception history, and meaning for understanding the world and how to live in it. By "constructed" I mean put together based on evidence, assumptions, paradigms, and agendas by present-day readers as well as an awareness of competing reconstructions and the presence of multiple perspectives in the biblical texts. ${ }^{7}$

The transformation that crossing this threshold prompts is the adoption of an evidence-based approach to biblical understanding that includes consideration of authorship, context, language, accuracy, textual integrity, and so forth, and an acceptance and appreciation for the contested and contingent nature of biblical knowledge. Students who have developed this threshold capability will understand the different ways that, for example, Pauline authorship of the letter to the Galatians may be used when constructing the early history of Jesus-followers. Further, grasping the constructed nature of historical understanding may be integrative in that it links history and text. It exposes the reciprocal relationship between historical reconstruction and textual interpretation as text informs historical context and reconstructed history provides a setting for interpreting the text. In the case of the letter to the Galatians, Paul's polemics against opponents within the early Jesus movement help construct a historical setting that includes conflicting understandings of the place of gentiles among Jesus-followers.

Finally, the constructed nature of biblical understanding may be conceptually troublesome as students are challenged to convert inert knowledge into evidence-based contingent knowledge. As discussed above, inert knowledge is knowledge that a student can recall for a test, but that the student does not actively connect to other knowledge (Meyer and Land 2003, 416-420). Students may know that Paul wrote Galatians and that he had opponents among the earliest followers of Jesus, but without integrating this into their understanding of early Christian practice and belief - that is, if this remains inert - they may mistakenly take Galatians as standard for all early Jesus followers. Whereas the first TC is troublesome for students' identity by highlighting their tacit knowledge, this second TC may be troublesome as students are pushed to activate inert knowledge.

\section{Everything is an argument}

A third concept that may be an especially important TC for the biblical studies classroom is the recognition that "everything is an argument." ${ }^{8}$ By "everything," I mean all elements of the biblical texts as well as these same elements present in the reception history of the biblical texts, including the immediate classroom. In terms of the biblical texts, the TC that everything is an argument emphasizes the way that features of the text such as language, genre, structure, rhetoric, word choice, and so forth, are shaped by the interests, ideology, and worldview of the authors/redactors/transmitters. It thereby combines elements of the TC's representation and formal expression in the discipline of literature as well as the recognition of the limits of particular media in the discipline of history.

Crossing this threshold is transformative as students learn to approach the biblical texts as artifacts created by real persons for specific purposes. The awareness that everything is an argument enables students to avoid simply equating, for example, the historical books of 1-2 Kings with "real" history and approach them as historical sources that present Israelite history from a Judean perspective, with an interest in cultic centralization, and structured by a deuteronomistic understanding of divine reward and punishment (see for example, Collins 2018). This awareness enables students to make sense of attempts to reconstruct ancient Israelite history and prepares them to critically compare competing reconstructions. This TC is also integrative insofar as textual features (such as repetition) are seen to reflect the specific interests of real (and often unknown) authors, redactors, and transmitters, which are themselves shaped by historical context. In the case of 1-2 Kings, elements such as the emphasis on the centralization of the cult, and the reforms of Josiah as the narrative climax, enable scholars to suggest probable dates and provenance, and historical forces impacting the writer and redactors. The awareness that everything is an argument may also be troublesome, especially for students with a flat understanding of the biblical texts as authoritative and directly applicable to their life circumstances. For students with this (often tacit) approach to the Bible, consideration of the ideological motives of the writers of 1-2 Kings and the possibilities of historical distortion or inaccuracy may represent alien knowledge (knowledge coming from a perspective in conflict with one's own).

\footnotetext{
7 For example, Margaret Mitchell writes that interpreting Paul "is fundamentally an artistic exercise in conjuring up and depicting a dead man from his ghostly images in the ancient text, as projected on a background composed from a selection of existing sources. All these portraits are based upon a new configuration of the surviving evidence, set into a particular, chosen, framework" $(2002,428)$.

8 This phrase is inspired by the title of a popular introductory writing textbook, Everything's an Argument (Lunsford, Ruszkiewicz, and Walters 2018).
} 
The relevance of the academic study of the Bible

The fourth concept that I suggest represents a portal opening previously inaccessible conceptual space is the contemporary relevance of the academic study of the Bible. While the relevance of history may be the acquisition of the critical thinking skills needed for the super-complexity of present-day life, I see the relevance of biblical studies to be its role in student meaning-making. The Bible's relevance for students with a commitment to it as a normative, authoritative text may be self-evident. For other students, the Bible remains important for meaning-making because of its impact on contemporary culture. Shiela McGinn notes four reasons students in a North American context should know something about the Bible: (1) It is a classic of Western literature, (2) it has been formative for American culture, (3) it shaped Western law, and (4) it continues to be used in contemporary politics (Webster et al. 2012, 273). The relevance of biblical studies falls outside disciplinary "ways of thinking and practicing." However, like TCs in general, without grasping the relevance of subject significance, deep learning will not occur (Zull 2002). Further, it is arguably transformative, integrative, and troublesome and therefore can be usefully treated as a TC in biblical studies.

First, the transformation involved in crossing this threshold involves a shift from viewing the subject as inconsequential, or even threatening, to a perspective that sees an academic approach to the Bible as an asset for personal meaning-making. I see a two-fold relevance to the academic study of the Bible, distinguished by two different student perspectives. Some students feel threatened by the investigative questions that are central to an academic study of their sacred texts. For these students, navigating the threshold involves gaining an appreciation of what an academic approach to their sacred texts offers their own meaning-making processes by opening new avenues of inquiry and advocating dispassionate evidence-based argumentation. Other students may see the Bible, and religion more generally, as increasingly irrelevant for contemporary life. For these students, navigating the threshold involves grasping the impact of these texts on societal factors shaping their own experience.

Second, an understanding of the relevance of biblical studies is integrative insofar as it connects textual interpretation with reception history and invites the student to see their own process of meaning-making as participating in a long history of other persons reading the same texts in foreign cultures for different reasons. Finally, engaging in the academic study of biblical texts can be troublesome for students as ritual knowledge is infused with meaning, making their student identity vulnerable. Ritual knowledge is knowledge that lacks meaning - for example, the knowledge that there are four gospels (Meyer and Land 2003, 417). When students realize the significance of the four-fold gospel for contextualizing the earliest traditions about Jesus and the historical Jesus - for example, by demonstrating the literary relationship between the synoptic Gospels (Matthew, Mark, and Luke) and the role of the writer in placing the same story in different narrative and historical contexts - this ritual knowledge becomes meaningful, yet potentially troublesome for student identity as they realize that the gospels cannot be read as straight historical accounts of the life and ministry of Jesus.

\section{The effects of treating the biblical text as authoritative}

The final idea that I suggest represents a TC in biblical studies is the impact of the Bible's authoritative status. This includes its impact on textual interpretation, as well as its elevated impact on culture and society due to this status within communities of practice. Like the other TCs, this final TC is arguably transformative, integrative, and troublesome. In addition, it is bounded (a fifth TC characteristic), insofar as it demarcates the disciplinary boundary between history and biblical studies.

First, the transformative perception shift that this concept occasions is for students to view the idea of textual authority as a contingent factor in their analysis of history, regardless of whether they themselves have a commitment to the authoritative status of the biblical text. So, for example, reading the New Testament as authoritative and normative may cause students to read Matthew's gospel in light of Pauline statements such as "no one will be justified by works of the law" (Gal 2:16). However, without this assumption, Matthew may be understood to teach righteousness by Torah-observance (especially Matt 5:17-20; Saldarini 1994, 124-164). The perception shift is not that students adopt one or the other assumption, but that they realize the impact of the status they accord to the Bible on their understanding of the biblical texts.

Second, this approach integrates the authoritative status of these texts for communities of practice into students' biblical understanding by highlighting its impact on textual interpretation, reception history, and so forth. To continue the above example, the dominant reception history of reading Matthew 5:20 ("unless your righteousness exceeds that of the scribes and Pharisees, you will never enter the kingdom of heaven") to call for an alternative type of righteousness, 
can be explained by the authority accorded to the text by nearly all early interpreters (Runesson 2016, 62). This can then raise questions about the impact of communities of practice on the transmission, selection, and editing of the texts, and hence on reconstructions of the earliest history of the Jesus movement. Finally, integrating the concept of authority into students' analysis of the Bible can be troublesome because it investigates a particular piece of tacit knowledge (the Bible is/is not authoritative), making students' relation to the Bible's authority vulnerable, potentially altering student identity.

In addition, this final TC is also bounded, a fifth TC characteristic outlined by Meyer and Land. The characteristic of boundedness refers to the way that many TCs explain only part, but not all, of the subject area, and may serve to demarcate disciplinary boundaries (Meyer and Land 2003, 416). The authority conveyed to the biblical text by communities of practice demarcates the discipline of biblical studies from that of history. Biblical studies may also share this TC with the discipline of classics insofar as select works of Greek and Latin writers have been treated as quasi-canonical classics for Western culture.

\section{Threshold concepts in other disciplines}

In addition to history and literature, other related disciplines have identified TCs. While these did not factor into my list of TCs for ways of thinking and practicing in biblical studies, they may be useful for individual topical courses in biblical studies. Some of the more interesting possibilities are noted here. In gender studies, the TCs of equality (Dyer and Hurd 2018), privilege, oppression, and social construction of gender (Launius and Hassel 2015) may be used to structure a course on gender and the Bible. The TC of othering from cultural studies (Cousin 2006) may be usefully applied in a course on, for example, postcolonial interpretation of the Bible. In addition, linguists have suggested that second language acquisition may function as a TC (Carson 2017). This may provide new approaches to teaching biblical Hebrew, Aramaic, and Greek to first-time language students.

\section{Classroom Implementation}

Identifying TCs for the biblical studies classroom matters only insofar as they may be deployed in the classroom to enhance student learning. Fortunately, significant work has been done developing strategies to assist students in successfully navigating thresholds (for example, Land, Meyer, and Flanagan 2016). Threshold concepts may be integrated into the classroom at a variety of levels from a full curriculum restructuring to individual activities that assist students navigating a specifically troublesome TC. The following guidelines maintain an explicit focus on TCs and take into account variation in student learning. I address course design, presentation strategies, classroom activities, and assessment and provide practical examples from the biblical studies classroom.

\section{Course design}

At the level of course design, comprehension of TCs may be listed as intended learning outcomes in the course syllabus (Timmermans and Meyer 2017, 8). Developing a threshold capability often occasions other types of transformation related to ways of being or knowing. Therefore, additional learning outcomes may include, for example, "thinking like a biblical scholar." For courses structured around TCs, sufficient time should be allotted for students to navigate the threshold. Sally Male suggests separating TCs by at least one week and revisiting them throughout the course in order to give students time to navigate the liminal space of the threshold $(2012,37)$. Students can learn concepts that are not troubling outside of class in, for example, reading assignments or written responses. This focus on TCs at the course level represents a "less is more" approach that avoids the information overload that triggers surface approaches to learning (van Merrienboer, Kirschner, and Kester 2003).

I find Jason Davies's trifold approach (2016) of framing, struggle, and integration (for teaching TCs in ancient religion) easily transferable to biblical studies. He advocates a structured approach that, after introducing a TC (framing), provides students multiple opportunities to experiment with the new concept (struggle), before asking students to apply the TC in practice (integration). In the subsequent sections, I follow his structured approach and provide practical examples meant to help students navigate TCs in the biblical studies classroom. 


\section{Presentation strategies}

Teaching TCs differs by disciplinary context, course level, and student relation to the TC (Meyer and Land 2007). Therefore, there is no single approach to presenting material, designing classroom activities, and assessing student learning. However, some guidelines have been shown to be effective. For example, while presenting material, the teacher may model the mental operations for students. Middendorf and Shopkow (2017) suggest introducing a TC by using an analogy from outside the discipline to show students which "mental muscles" to activate (Davies's "framing" [2016]). For example, I introduce the TC that "everything is an argument" by analyzing Nike's Colin Kaepernick banner advertisement, an image that students immediately recognize and, as an advertisement, clearly makes an argument. This recent, well-known image consists of the text "Believe in something. Even if it means sacrificing everything," superimposed on a close-up of Kaepernick's unsmiling face with the Nike swoosh and slogan "Just do it" running along the bottom (Kaepernik 2018). Alongside the advertisement I list three questions: (1) "What is the argument of this ad?" (2) "What did Nike hope to accomplish?" and (3) "Why did Nike run this ad?" After giving students time to discuss the questions with classmates, I walk through each, making my mental operations explicit by relating the components of the advertisement to its cultural and corporate setting. We begin addressing the first question by considering the relationship between the superimposed text and the former NFL quarterback Colin Kaepernick. We note that the first part ("Believe in something") alludes to Kaepernick's activism for racial justice and, most prominently, protesting police brutality and racial inequality by kneeling during the United States' national anthem. We then note that the second part ("Even if it means sacrificing everything") alludes to the widely held belief that Kaepernick was unable to find a job in the National Football League because of his protests. We then consider Kaepernick's direct, unsmiling gaze into the camera, suggesting that this expression was chosen to portray him as sincere rather than opportunistic or selfish, as argued by critics. Finally, we address what new resonances Nike's multivalent slogan "Just do it" takes on in this context, concluding that it is not just about motivation - such as going out for your first run - but also activism. The answers to the second and third questions quickly follow: students voluntarily note that Nike sought to position itself on one side of the United States' cultural and political wars and agree that Nike ran the ad campaign to boost merchandise sales, betting on the long-term payoff of racial justice.

The assignment for the following class period is to read the book of Ruth and write a one-page response to the same three questions, tailored to Ruth. Ruth is a useful discipline-specific example of the TC "everything is an argument" because it is short and has a number of good candidates for the writer's argument (another more complex example is Jonah). Most students discern an argument similar to "God looks out for the vulnerable." After discussing themes and scenes that support this type of narrative argument, I note that God only directly acts once in Ruth (4:13), and ask whether anyone found different arguments. We eventually agree that a defense of the Davidic line (noting the Davidic genealogy [4:17-22] and divinely-assisted birth [4:13]) and a defense of exogamy (noting Ruth's willing assimilation [1:16-17] and reception of all the people's blessing [4:11]) are other possible arguments. We conclude by noting that, unlike Nike's Colin Kaepernick advertisement, Ruth's unknown writer(s) and provenance make conclusions about authorial argument tentative, but it does not mean that the writer makes no argument.

\section{Classroom activities}

Classroom activities enable students to experiment with the new concept (Davies's "struggle" [2016]). They should be designed to take into account variation in the TC and in student learning, and to require students to make the mental operations explicit (Nicola-Richmond et al. 2018, 106). Online interactive tutorials may help account for variation in student learning by allowing students to navigate the threshold at their own pace (Khawaja et al. 2013). Making the mental operations observable enables immediate feedback that can guide students' continued practice (Timmermans and Meyer 2017, 11). Semi-structured activities such as debating, explaining, and sketching enable students to experience variation in the features of the concept, its manifestation in different contexts, and its application (Male 2012, 39-40).

In order for students to experience the effects of treating the biblical text as authoritative (TC 4), I find the following combination of activities useful over the course of three class periods. In a first class period, I project Matthew 5:17-209 and ask students to answer two questions on the classroom whiteboard: According to Matthew's Jesus, (1) "Why will the scribes and Pharisees not enter the kingdom?" and, (2) "What might the scribes and Pharisees do to gain kingdom en-

9 Matthew 5:17-20: "Do not think that I have come to abolish the law or the prophets; I have come not to abolish but to fulfill. For truly I tell you, until heaven and earth pass away, not one letter, not one stroke of a letter, will pass from the law until all is accomplished. Therefore, whoever breaks one of the least of these commandments, and teaches others to do the same, will be called least in the kingdom of heaven; but whoever does them and teaches them will be called great in the kingdom of heaven. For I tell you, unless your righteousness exceeds that of the scribes and Pharisees, you will never enter the kingdom of heaven." 
trance?" By making all answers visible I can tailor discussion to responses as students compare their answers with those of their peers. In our discussion, we focus on those answers to the second question that represent some variation of "accept Christ" or "accept Christ's righteousness," an answer that seems self-evident to many. One volunteer then writes the logic of this proposed answer on the whiteboard in order to make the mental operations explicit. After asking students to point out where an alternative form of righteousness is noted in Matthew 5:17-20, I write Romans 3:21-22 ${ }^{10}$ alongside the student's logic, emphasizing the influence of (one understanding of) Paul in this reading of Matthew 5:17-20. We then note elements in the text that suggest another answer to this second question: scrupulous Torah observance. I characterize reading Matthew in light of Paul as reading "canonically" and trace the logic of how a canonical approach to reading may be seen as a natural implication of the authoritative status of the biblical texts.

As a follow-up example to illustrate how the authoritative status of the biblical texts manifests itself in different contexts, I ask students to consider the meaning of "freedom" in Galatians 5:1, ${ }^{11}$ first without, and later with, the epistolary context. After having worked through one previous example (Matthew 5:17-20), students more readily see how "freedom from sin," although contextually inaccurate, may be a common misunderstanding of Galatians 5:1 and how the personal relevance of biblical texts may be an assumed implication of the authoritative status of the biblical texts for some readers. By illustrating another way that treating the biblical text as authoritative may manifest itself, this second example helps students avoid equating biblical authority with reading canonically and raises the question of what other ways this TC may manifest itself.

Before the following class period, students read the Chicago Statement on Biblical Inerrancy (1978) in preparation for a class debate. Four students represent the signees and argue in favor of the premise that "Recognition of the total truth and trustworthiness of Holy Scripture is essential to full grasp and adequate confession of its authority" (Chicago Statement on Biblical Inerrancy, 1978). Four other students argue against this premise, while still adopting the assumption of biblical authority for the sake of the debate. Students are encouraged to take a position they do not necessarily hold in order to focus learning on why or why not inaccuracies may seem permissible in authoritative texts. The students who are not part of the debate submit a two-page peer review response evaluating the quality of the arguments. This activity, while introducing another manifestation of the effects of biblical authority (inerrancy), forces students to focus on variation in this TC and the thought processes associated with moving from adherence to biblical authority to its implications. After the debate, we briefly address Origen's three senses of scripture as an alternative manifestation of the Bible's authority, noting how Origen positions the impossibilities and immoralities in the biblical text as necessary pointers to the deeper spiritual meaning (Ludlow 2013, 87-91).

In a final, third class period, we do two activities meant to allow students to apply their understanding of the effects of treating the Bible as authoritative (Davies's “integration” [2016]). First, I ask students to collaboratively sketch the historical scenarios that may have resulted in the two different explanations for the name Akeldama ("field of blood") in Matthew 27:3-8 (bought with blood money) and Acts 1:18-19 (Judas's blood spilt there) and address what effect treating the biblical text as authoritative may have on the choice of a preferred explanation. This activity links the interpretation of possible textual inaccuracy with the role of biblical authority in historical reconstruction. The final activity involves students in small groups comparing and contrasting the depiction of the centurion's reaction to Jesus's death in Matthew 27:50-54 and Mark 15:37-39. Students are asked to list significant differences between the two accounts and answer two questions: (1) "In what way do the differences allow or restrict different characterizations of the centurion's response?" and (2) "How might treating the biblical text as authoritative impact these interpretive options?" This order of operations requires students to practice moving from textual features to interpretive options - in Matthew the centurion is sincere, while in Mark he may be sarcastic (Eubank 2014, 267) - and then to consider the effects of biblical authority on their interpretive choices (for example, two different depictions of the centurion; a presumed first confession of gentile faith as, instead, mockingly sarcastic). These two final application activities revisit different manifestations of the effects of biblical authority from previous activities in order to provide repeated exposure to the TC and require students to demonstrate their ability to analyze the effects of treating the biblical text as authoritative as a contingent factor.

\footnotetext{
10 Romans 3:21-22: "But now, apart from law, the righteousness of God has been disclosed, and is attested by the law and the prophets, the righteousness of God through faith in Jesus Christ for all who believe."

11 "For freedom Christ has set us free. Stand firm, therefore, and do not submit again to a yoke of slavery."
} 
Assessment

A wide variety of tools have been used to assess whether students have crossed a threshold (Nicola-Richmond et al. 2018, 107-108). Formative assessment should be dynamic and ongoing, providing the teacher repeated opportunities to evaluate student learning and provide immediate feedback. In addition, self- and peer-assessment have unique potential to increase student awareness of their own learning and their location to the TC (Meyer et al. 2016, 199-200). If classsize permits, I like making learning visible on white boards, discussions, and debates, as discussed in the examples of classroom activities.

In general, summative assessment should require students to demonstrate the mental operations required by the TC (Davies's “integration” [2016]), rather than simple information recall (Male 2012, 40). This may involve explaining or justifying an answer, or solving a new problem by the same mental operations practiced in class activities. For example, in a New Testament introductory course, I assign a final take-home assignment response to When Christians Were Jews: The First Generation (Fredriksen 2018). This final project allows me to assess students' grasp of the constructed nature of biblical understanding (TC 2). This short (182 reading pages, assigned over the last three weeks of class), accessible, and engaging reconstruction of Christian origins presents the earliest Christ-followers as a temple-centered Jewish movement awaiting the immanent restoration of the Davidic monarchy. As an account of Christian origins that contrasts with most students' preformed understanding and that clearly distinguishes historical evidence from reconstructed history, Fredriksen's book allows students to evaluate the plausibility of her reconstruction through reference to the book and historical sources, demonstrating their grasp of the constructed nature of biblical understanding and ability to perform the associated mental operations.

\section{Conclusion}

This paper introduces a preliminary list of five TCs for the discipline of biblical studies: (1) The biblical world as a foreign country; (2) the constructed nature of biblical understanding; (3) the concept that everything is an argument; (4) the relevance of the academic study of the Bible, and (5) the effects of treating the biblical text as authoritative. The identification of TCs in biblical studies enables teachers to emphasize potentially troublesome concepts that are essential for student progress and to aid students in navigating these thresholds by proven strategies developed in other disciplines and transferable to biblical studies. By engaging TCs in the disciplines of history and literature this preliminary set provides a theoretically informed basis for further investigation that awaits refinement through empirical data from teachers, students, and educational developers through a transactional curriculum inquiry.

\section{BIBLIOGRAPHY}

American Association of University Professors. 1970. 1940 Statement of Principles on Academic Freedom and Tenure with 1970 Interpretive Comments. Retrieved from https://www.aaup.org/file/1940\%20Statement.pdf.

Andrews, T., and F. Burke. 2007. “What Does it Mean to Think Historically?” Perspectives on History 45: 32-35. Retrieved from https://www.historians.org/publications-and-directories/perspectives-on-history/january-2007/what-does-itmean-to-think-historically.

Ascough, Richard S. 2020. “Crossing the Threshold by Unlearning the 'Truth' in Biblical Studies.” The Wabash Center Journal on Teaching 1(1): 81-82. https://doi.org/10.31046/wabashjournal.v1i1.1583.

Association for College and Research Libraries. 2015. Framework for Information Literacy for Higher Education. Retrieved from http://www.ala.org/acrl/sites/ala.org.acrl/files/content/issues/infolit/Framework_ILHE.pdf.

Baillie, C., Bowden, J., and J. Meyer. 2013. “Threshold Capabilities: Threshold Concepts and Knowledge Capability Linked through Variation Theory." Higher Education 65(2): 227-246. 
Barradell, S. 2013. “The Identification of Threshold Concepts: A Review of Theoretical Complexities and Methodological Challenges." Higher Education 65: 265-276.

Calder, L. 2006. “Uncoverage: Toward a Signature Pedagogy for the History Survey.” Journal of American History 92: $1358-1370$.

Carson, L. 2017. “Second Language Use as a Threshold Concept: Reconceptualising Language Learning Journeys.” International Journal of Education 9(2): 34-43. https://doi.org/10.5296/ije.vgi2.11315.

The Chicago Statement on Biblical Inerrancy. 1978. International Council on Biblical Inerrancy. Retrieved from https:// www.etsjets.org/files/documents/Chicago_Statement.pdf.

Collins, J. J. 2018. Introduction to the Hebrew Bible. 3rd ed. Minneapolis, MN: Fortress.

Cousin, G. 2006. "Threshold Concepts, Troublesome Knowledge and Emotional Capital: An Exploration into Learning about Others." In Overcoming Barriers to Student Understanding: Threshold Concepts and Troublesome Knowledge, edited by J. Meyer and R. Land, 134-147. London, UK: Routledge.

Cousin, G. 2009. Researching Learning In Higher Education: An Introduction to Contemporary Methods and Approaches. New York, NY: Routledge.

Coventry, M., Felten, P., Jaffee, D., O’Leary, C., Weis, T., and S. McGowan. 2006. “Ways of Seeing: Evidence and Learning in the History Classroom." Journal of American History 92: 1371-1402.

Davies, J. 2016, September 1. “Threshold Concepts and Teaching Ancient Religion: A Trifold Approach \#2.” Teaching and Learning about Ancient Religions. Retrieved from https://tlarblog.wordpress.com/2016/09/01/threshold-conceptsand-teaching-ancient-religion-a-trifold-approach-2-jason-davies-ucl/.

Davies, P., and J. Mangan. 2007. "Threshold Concepts and the Integration of Understanding in Economics." Studies in Higher Education 32: 711-726.

Díaz, A., Middendorf, J., Pace, D., and L. Shopkow. 2008. “The History Learning Project: A Department “Decodes” Its Students." Journal of American History 94: 1211-1224.

Dyer, S., and F. Hurd. 2018. “Equality as a Threshold Conception: Challenging Future Manager’s Perceptions. Equality, Diversity and Inclusion: An International Journal 37(7): 683-97.

Eubank, N. 2014. “Dying with Power: Mark 15,39 From Ancient to Modern Interpretation.” Biblica 95(2): 247-268. https://www.bsw.org/biblica/vol-95-2014/dying-with-power-mark-15-39-from-ancient-to-modern-interpretation/564/.

Flanagan, M. 2019. “Threshold Concepts: Undergraduate Teaching, Postgraduate Training, Professional Development and School Education." Retrieved from http://www.ee.ucl.ac.uk/ mflanaga/thresholdsH.html.

Fredriksen, P. 2018. When Christians Were Jews: The First Generation. New Haven, CT: Yale University Press.

Gibbs, G., and M. Coffey. 2004. "The Impact of Training of University Teachers on their Teaching Skills, their Approach to 
Teaching and the Approach to Learning of their Students." Active Learning in Higher Education 5 (1): 87-100.

Gilmour, R. 2016. “The Exodus in the Bible's Teaching and Our Teaching of the Bible: Helping to Reconcile Faith and Critical Study of the Bible through Threshold Concept Theory." Journal of Adult Theological Education 13: 116-127.

Heiser, M. S. 2008. "Monotheism, Polytheism, Monolatry, Or Henotheism? Toward an Assessment of Divine Plurality in the Hebrew Bible." Bulletin for Biblical Research 18: 1-30.

Kaepernick, Colin. 2018. Twitter post. Sept 3, 2018, 12:20 PM. https://twitter.com/kaepernick7/status/103669551325143 4498?lang=en.

Khawaja, M. A., Prusty, G. B., Ford, R. A. J., Marcus, N., and C. Russell. 2013. "Can More Become Less? Effects of an Intensive Assessment Environment on Students' Learning Performance." European Journal of Engineering Education 38(6): 631-651.

Killen, P. O. 2011. Review of Threshold Concepts within the Disciplines, by R. Land, J. H. F. Meyer, and J. Smith. Teaching Theology and Religion 14: 200-202.

Killen, P. O., and E. V. Gallagher. 2013. "Sketching the Contours of the Scholarship of Teaching and Learning in Theology and Religion." Teaching Theology and Religion 16: 107-124.

Land, R., Meyer, J. H. F., and M. T. Flanagan (Eds.). 2016. Threshold Concepts in Practice. Rotterdam, the Netherlands: Sense.

Land, R., Meyer, J. H. F., and J. Smith. 2008. Threshold Concepts Within the Disciplines. Rotterdam, the Netherlands: Sense.

Launius, C., and H. Hassel. 2015. Threshold Concepts in Women's and Gender Studies: Ways of Seeing, Thinking, And Knowing. New York, NY: Routledge.

Lévesque, S. 2008. Thinking Historically: Educating Students for the Twenty-first Century. Toronto, Canada: University of Toronto Press.

Liew, Tat-siong Benny. 2020. “Teaching the Bible as a Threshold Concept in a Liberal Arts Context.” The Wabash Center Journal on Teaching 1(1): 79-80. https://doi.org/10.31046/wabashjournal.v1i1.1582.

Ludlow, M. 2013. "Spirit and Letter in Origen and Augustine." In The Spirit and the Letter: A Tradition and a Reversal, edited by P. S. Fiddes and G. Bader, 87-102. London, UK: Bloomsbury.

Lunsford, A. A., Ruszkiewicz, J. J., and K. Walters. 2018. Everything's an Argument. 8th ed. Boston, MA: Bedford/St. Martin's.

Male, S. 2012. Engineering Thresholds: An Approach to Curriculum Renewal: Guide for Engineering Educators on Curriculum Renewal Using Threshold Concepts. Sydney, Australia: University of Western Australia. Retrieved from http:// www.ecm.uwa.edu.au/_data/assets/pdf_file/0018/2323017/PP10_1607_Baillie_Inventory_2012.pdf.

McWhirter, Jocelyn. 2020. “All Interpretations Are Subjective.” The Wabash Center Journal on Teaching 1(1): 83-84. 
https://doi.org/10.31046/wabashjournal.v1i1.1584.

Meyer, J. H. F., and R. Land. 2002. "Threshold Concepts and Troublesome Knowledge." Presented at the Improving Student Learning Symposium, Brussels, September.

Meyer, J. H. F., and R. Land. 2003. “Threshold Concepts and Troublesome Knowledge: Linkages to Ways of Thinking and Practising within the Disciplines." In Improving Student Learning: Theory and Practice Ten Years On, edited by C. Rust, 412-424. Oxford, UK: Oxford University Press.

Meyer, J. H. F., and R. Land. 2005. "Threshold Concepts and Troublesome Knowledge (2): Epistemological Considerations and a Conceptual Framework for Teaching and Learning." Higher Education 49: 373-388.

Meyer, J. H. F., and R. Land. 2006. "Threshold Concepts and Troublesome Knowledge: An Introduction." In Overcoming Barriers to Student Understanding: Threshold Concepts and Troublesome Knowledge, edited by J. H. F. Meyer and R. Land, 3-18. New York, NY: Routledge.

Meyer, J. H. F., and R. Land. 2007, August 17. "Stop the Conveyor Belt, I Want to Get Off." Times Higher Education Supplement 1807 .

Meyer, J. H. F., Land, R., and P. Davies. 2008. "Threshold Concepts and Troublesome Knowledge (4): Issues of Variation and Variability." In Threshold Concepts Within the Disciplines, edited by R. Land, J. H. F. Meyer, and J. Smith, 59-74. Rotterdam, the Netherlands: Sense.

Meyer, R., Knight, D. B., Baldock, T. E., Callaghan, D. P., McCredden, J., and L. O’Moore. 2016. “What To Do with a Threshold Concept: A Case Study." In Threshold Concepts in Practice, edited by Ray Land, J. H. F. Meyer, and M. T. Flanagan, 195-209. Rotterdam, the Netherlands: Sense.

Middendorf, J., and L. Shopkow. 2017. Overcoming Student Learning Bottlenecks: Decode the Critical Thinking of Your Discipline. Sterling, VA: Stylus.

Mitchell, M. 2002. The Heavenly Trumpet: John Chrysostom and the Art of Pauline Interpretation. Louisville, KY: Westminster John Knox.

Morales, H., and M. Barnes. 2018. "The Baltimore Mural Project: An Approach to Threshold Concepts in Religious Studies." Teaching Theology and Religion 21: 185-196.

Mossley, D. 2017. Reflecting on Theshold Concepts: An Introductory Tool. York, UK: Higher Education Academy.

Mudge, P. 2014. “ ‘Crossing Frontiers Without a Map': The Role of Threshold Concepts and Problematic Knowledge in Religious Education and Spirituality." Waikato Journal of Education 19: 51-68.

Nicola-Richmond, K., Pépin, G., Larkin, H., and C. Taylor. 2018. “Threshold Concepts in Higher Education: A Synthesis of the Literature Relating to Measurement of Threshold Crossing." Higher Education Research and Development 37(1): $101-114$.

Pace, D. 2008. “Opening History’s ‘Black Boxes’: Decoding the Disciplinary Unconscious of Historians.” In The University and its Disciplines: Teaching and Learning Within and Beyond Disciplinary Boundaries, edited by C. Kreber, 
96-104. London, UK: Routledge.

Perkins, D. 1999. “The Many Faces of Constructivism.” Educational Leadership 57: 6-11.

Reimann, N., and I. Jackson. 2006. “Threshold Concepts in Economics: A Case Study." In Overcoming Barriers to Student Understanding: Threshold Concepts and Troublesome Knowledge, edited by J. H. F. Meyer and R. Land, 115-133. New York, NY: Routledge.

Runesson, A. 2016. Divine Wrath and Salvation in Matthew: The Narrative World of The First Gospel. Minneapolis, MN: Fortress.

Saldarini, A. J. 1994. Matthew's Christian-Jewish Community. In Chicago Studies in the History of Judaism. Chicago, IL: University of Chicago Press.

Saroyan, A., and K. Trigwell. 2015. “Higher Education Teachers' Professional Learning: Process and Outcome.” Studies in Educational Evaluation 46: 92-101.

Sendziuk, P. 2014. “Helping Students to ‘Think Historically’ by Engaging with Threshold Concepts.” In Threshold concepts: From Personal Practice to Communities of Practice, edited by C. O’Mahony, A. Buchanan, M. O'Rourke, and B. Higgs, 178-183. Cork, Ireland: NAIRTL.

Shanahan, M., and J. H. F. Meyer. 2006. "The Troublesome Nature of a Threshold Concept in Economics." In Overcoming Barriers to Student Understanding: Threshold Concepts and Troublesome Knowledge, edited by J. H. F. Meyer and R. Land, 100-114. New York NY: Routledge.

Sloman, John, and Alison Wride. 2009. Economics. 7th ed. Harlow, England: Financial Times-Prentice Hall.

Timmermans, J. A., and J. H. F. Meyer. 2017. “A Framework for Working with University Teachers to Create and Embed 'Integrated Threshold Concept Knowledge' (ITCK) in their Practice." International Journal for Academic Development, $\mathrm{o}(0), 1-15$.

Trigwell, K., and M. Prosser. 2004. “Development and Use of the Approaches to Teaching Inventory.” Educational Psychology Review 16: 409-424.

Trigwell, K., Prosser, M., and F. Waterhouse. 1999. “Relations Between Teachers' Approaches to Teaching and Students' Approaches to Learning." Higher Education 37: 57-70.

Van Maaren, J. 2018a. “The Contribution of Threshold Concepts for Creating a Discipline of Pedagogy in Biblical Studies." Presented at The Pedagogy of Bible Education conference, Tel Aviv, December.

Van Maaren, J. 2018b. "Transformative Concepts and Troublesome Knowledge: Toward a Consensus of Threshold Concepts in Biblical Studies." Presented at the annual conference of the Society of Biblical Literature, Denver, CO, November.

Van Merrienboer, J. J. G., Kirschner, P. A., and L. Kester. 2003. “Taking the Load Off a Learner's Mind: Instructional Design for Complex Learning." Educational Psychologist 38(1): 5-13. 
Vidal, N., Smith, R., and W. Spetic. 2015. “Designing and Teaching Business and Society Courses from a Threshold Concept Approach." Journal of Management Education 39(4): 497-530.

Webster, J. S., Runions, E., Gallagher, E. V., Lopez, D. C., McGinn, S. E., Penner, T. C., and D. B. Howell. 2012. “Student Learning Outcomes for Biblical Studies in the Liberal Arts." Teaching Theology and Religion 15: 262-283.

Wineburg, S. S. 1991. "On the Reading of Historical Texts: Notes on the Breach between School and Academy." Education Research Journal 28: 495-519.

Wineburg, S. S. 2001. Historical Thinking and Other Unnatural Acts. Philadelphia, PA: Temple University Press.

Wisker, G. 2015. Teaching Literature: Contemporary Gothic, Threshold Concepts, Social Justice, and Dialogue. In Higher Education Academy (HEA) Innovative Pedagogies Series. York, UK: Higher Education Academy. Retrieved from https://www.heacademy.ac.uk/system/files/gina_wisker_final_o.pdf.

Wisker, G., Cameron, S., and M. Antoniou. 2007. Connotations and Conjunctions: Threshold Concepts, Curriculum Development, and the Cohesion of English Studies. Brighton, UK: English Subject Centre.

Zull, J. E. 2002. The Art of Changing the Brain: Enriching the Practice of Teaching by Exploring the Biology of Learning. Sterling, VA: Stylus.

\section{ABOUT THE AUTHOR}

John Van Maaren completed his PhD in Early Christianity at McMaster University in Ontario, Canada. He has nine years teaching experience with secondary, undergraduate, graduate, and life-long learning students in classroom, online, and community settings. 